\title{
Increased outburst flood hazard from Lake Palcacocha due to human-induced glacier retreat
}

\author{
Stuart-Smith, R.F. ${ }^{1,2^{*}}$, Roe, G.H. ${ }^{2}$, Li, S. ${ }^{1,3}$, \& Allen, M.R. ${ }^{1,4}$ \\ ${ }^{1}$ Environmental Change Institute, University of Oxford, Oxford OX1 3QY, UK \\ 2 Department of Earth and Space Sciences, University of Washington, Seattle, Washington 98195, USA \\ ${ }^{3}$ Oxford e-Research Centre, Department of Engineering Science, University of Oxford, Oxford OX1 3QG, UK \\ ${ }^{4}$ Department of Physics, University of Oxford, Oxford OX1 3PU, UK \\ * Correspondance to Rupert F. Stuart-Smith
}

A potential glacial lake outburst flood from Lake Palcacocha (Cordillera Blanca, Peru) threatens Huaraz, a city of 120,000 people. In 1941, an outburst flood destroyed one-third of the city and caused at least 1800 fatalities. Since preindustrial times, Lake Palcacocha has expanded due to the retreat of Palcaraju glacier. Here we present the first detailed study evaluating the anthropogenic contribution to the glacier's retreat and glacial lake outburst flood hazard. We find that the magnitude of human-induced warming equals between 85 and $105 \%$ (5-95\% confidence interval) of the observed $1{ }^{\circ} \mathrm{C}$ warming since 1880 in this region. Using observations and numerical models of the mass balance and glacier response, we conclude that it is virtually certain ( $>99 \%$ probability) that the retreat of Palcaraju glacier to the present day cannot be explained by natural variability alone, and that the retreat by 1941 represented an early impact of anthropogenic greenhouse gas emissions. Our central estimate is that the overall retreat is entirely attributable to the observed temperature trend, and that the resulting change in the geometry of the lake and valley has substantially increased the outburst flood hazard.

The worldwide retreat of mountain glaciers is one of the most prominent impacts of climate change in public discourse and an established consequence of anthropogenic climate change ${ }^{1-3}$, with Andean glaciers among the fastest retreating ${ }^{3,4}$. Mountain glacier lengths have decadal-to-multidecadal response times ${ }^{5,6}$ and act as lowpass filters of climate $e^{6,7}$. They therefore represent a purer signal of anthropogenic climate change than most other metrics. However, any individual glacier's response to climate change depends on its geographic and climatic setting ${ }^{1,2,8}$. An assessment of the human contribution to an individual glacier's retreat and hence changing glacial lake outburst flood (GLOF) hazard must quantify these factors and place the observed change in the context of the natural variability expected in the absence of anthropogenic climate change.

GLOFs are a dangerous hazard in deglaciating alpine environments, and downstream inundation from large outburst floods have caused serious damage to human settlements ${ }^{9}$ and infrastructure ${ }^{10}$. GLOFs can occur from englacial, subglacial, supraglacial, and proglacial lakes. GLOFs from proglacial lakes that form in the wake of a retreating glacier, such as Lake Palcacocha, are a response to the disequilibrium 
imposed on glacial landscapes by climate change ${ }^{11,12}$. They occur when an unstable moraine dam is breached or a moraine-overtopping wave is induced by a triggering event, such as a landslide or an avalanche $^{13}$. However, the anthropogenic influence on a specific GLOF has hitherto not been evaluated ${ }^{9}$. In the mid- $20^{\text {th }}$ Century, new proglacial lakes formed throughout the Cordillera Blanca as glacier termini receded ${ }^{14}$ and multiple fatal GLOFs were recorded, including from Lakes Ayhuinyaraju, Jancururish, Tumarina, and Palcacocha ${ }^{15}$. Ongoing GLOF hazard continues to require extensive mitigation and engineering efforts ${ }^{16,17}$. We focus here on Lake Palcacocha which currently threatens the city of Huaraz with a GLOF $3,11-13,16,18,19$.

Lake Palcacocha $\left(9^{\circ} 23^{\prime} 49^{\prime \prime} \mathrm{S} 77^{\circ} 22^{\prime} 47^{\prime \prime} \mathrm{W}\right)$ sits at the foot of Palcaraju glacier. Lichenometric dating of Palcaraju glacier's terminal moraine indicates a $17^{\text {th }}$-Century formation, which sets the maximum extent of the glacier in the last few centuries ${ }^{15,20}$. Photographic records of Palcaraju glacier (Fig. 1) show the 1939 terminus set well back from the terminal moraine, with an over-spilling Lake Palcacocha between the glacier's terminus and terminal moraine. In 1941, the breaching of Lake Palcacocha's moraine dam resulted in the Cordillera Blanca's deadliest GLOF of the $20^{\text {th }}$ Century ${ }^{15}$. The resulting debris flow destroyed one third of Huaraz and killed at least 1800 people ${ }^{12,14,21}$. Limited expansion of Lake Palcacocha was observed between 1948 and 1995, and lake area increased from 0.06 to 0.08 $\mathrm{km}^{2}$. The rapid retreat of Palcaraju glacier since 1995 has expanded the lake to an area of $0.49 \mathrm{~km}^{2}$ in $2018^{22}$. Two concrete overflow spillways were installed in the terminal moraine between 1972-1974. Until 2011, the lake-surface elevation had remained constant and lake volume grew as Palcacocha expanded into space previously occupied by the retreating glacier. In 2011, siphons were installed to lower the water surface by 3-5 m, although GLOF hazard remains high ${ }^{12}$. The most recent bathymetric survey found the volume of Lake Palcacocha was $17,403,353 \mathrm{~m}^{3}$ in $2016^{23}$, a 34-fold increase from the volume of the post-GLOF lake in 1941, making it the $4^{\text {th }}$ largest of the 35 glacial lakes with installed safety features in the Cordillera Blanca ${ }^{16}$. 

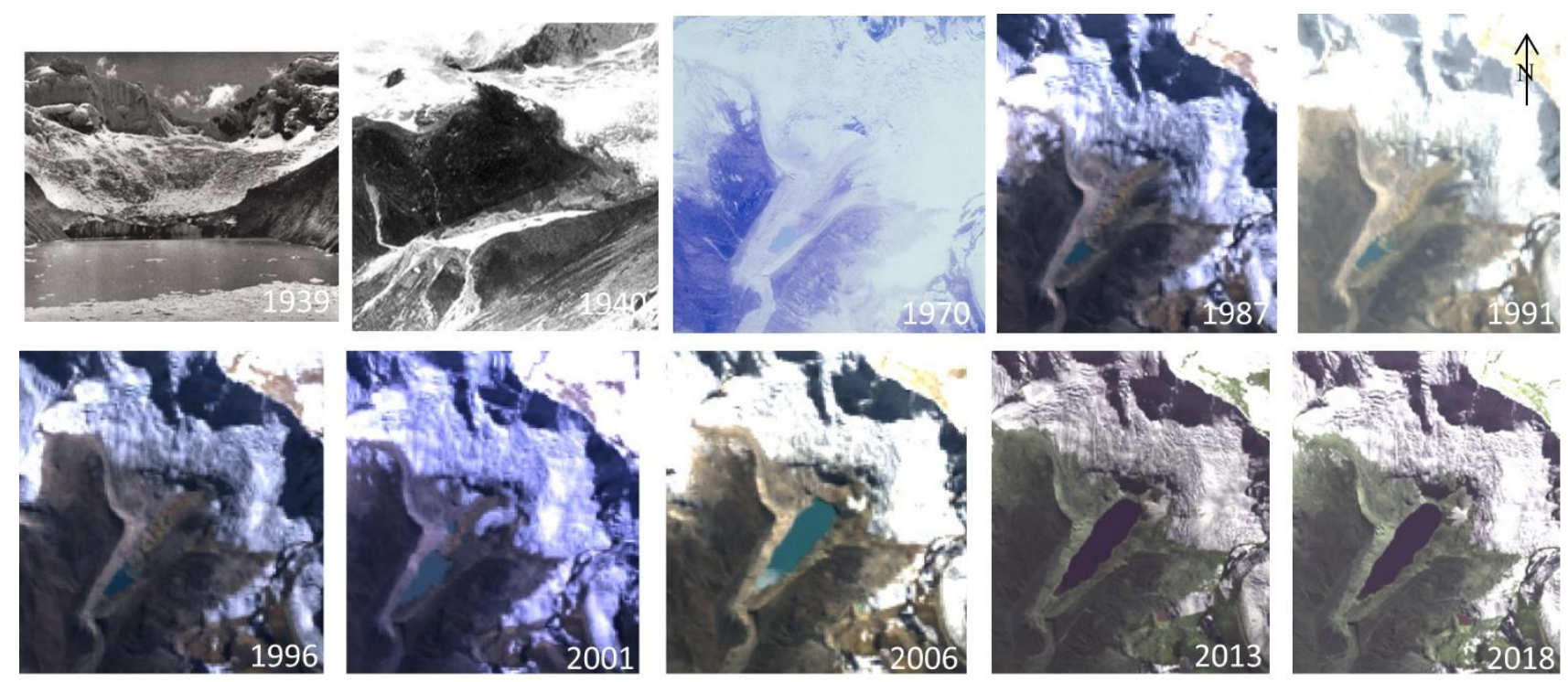

Figure 1: In situ (1939, 1940, 1970) and satellite (1987 onwards) images showing the evolution of Lake Palcacocha. This shows an over-spilling lake prior to the 1941 GLOF and then an initially minimal expansion followed by rapid lake growth due to the retreat of the glacier. The 1939 and 1940 images are from ref. ${ }^{24}$, and the 1970 aerial photograph is from the USGS EROS Archive (https://earthexplorer.usgs.gov/fgdc/4660/AR6148000307153). Images from 1987 onwards are from Landsat 5 (1987-2006) and Landsat 8 (2013, 2018) downloaded from the USGS Earth Explorer (https://earthexplorer.usgs.gov). All images from 1970-2018 were taken in July / August.

Any evaluation of the contribution of anthropogenic greenhouse gas (GHG) and aerosol emissions to changing GLOF hazard must consider the whole causal chain. Our study has three parts. We evaluate: (1) the anthropogenic contribution to the observed temperature trend; (2) the role of this trend in the observed retreat of Palcaraju glacier (comprising numerical modelling of the glacier and a statistical comparison of the observed retreat with the natural length variability); and (3) the role of the glacier's retreat in reshaping the valley and the resultant change in GLOF hazard.

\section{Attribution of Peru temperature trend to human activity}

Globally, virtually all long-term temperature variations since the mid-19 ${ }^{\text {th }}$ Century have been attributed to external forcing ${ }^{25}$. Following the approach taken by ref. ${ }^{26}$ and for Fig. 1.3 in ref. ${ }^{27}$, we obtain local annual-mean temperature (see Methods) from the relevant grid cell in the HadCRUT4Cowtan/Way (HadCRUT4-CW) dataset ${ }^{28,29}$ (Fig. 2a). The HadCRUT4-CW trend is well supported by regional observations (see Methods). To quantify the anthropogenic contribution to regional temperature change, we regress the observed temperatures in HadCRUT4-CW onto the Global Warming Index $(\mathrm{GWI})^{26}$, an estimate of the anthropogenic contribution to global externally-forced temperature change, over the period 1940-2018 (see Methods). This yields region-specific scaling 
factors for GWI. Regional anthropogenically-forced warming is the product of this scaling factor and the GWI anomaly relative to 1880 . For $1989-2018$, it is found to be equal to $95 \%$ ( $85-105 \%, 5-95 \%$ range, all percentages rounded to the nearest 5\%) of the observed temperature change over the same period. Uncertainty bounds are given by the inter-model range of regressions of the relevant grid cell in the control runs (with non-evolving pre-industrial conditions) of the Coupled Model Intercomparison Project Phase 5 (CMIP5) against GWI. Fig. 2a shows the observed temperature change for the HadCRUT4-CW grid cell containing Palcaraju glacier (black) and the temperature change in the same grid cell attributed to human GHG and aerosol emissions (orange). The correlation between regional temperatures and global anthropogenic warming with the estimated response to natural external climate drivers (solar variability and volcanic activity) is negligible.

\section{Attribution of Palcaraju glacier retreat to climate change}

The climate that a glacier experiences can be characterised by the vertical profile of its mass balance (i.e. accumulation minus ablation) ${ }^{30}$. We use a mass-balance profile (Fig. 2b) for Palcaraju glacier which, for the current climate, matches that observed on Shallap glacier $\left(9^{\circ} 29^{\prime} 24^{\prime \prime}\right.$ S, $77^{\circ} 20^{\prime} 24^{\prime \prime}$ W, a well-observed glacier approximately $10 \mathrm{~km}$ away, with similar aspect to Palcaraju $)^{30}$. The equilibrium line altitude (ELA, $\sim 4950 \mathrm{~m}$ in the current climate) denotes the altitude above which there is net accumulation and below which there is net ablation. A simple and robust method of quantifying the impact of climate change on glacier mass balance is via geometric shifts of the mass-balance profile in response to temperature and precipitation changes ${ }^{31-34}$. The climatological precipitation is important for the shape of the mass-balance profile but, on century timescales, precipitation trends are small and temperature changes dominate mass-balance changes ${ }^{33,35}$ (see also Methods and Supplementary Materials). Temperature changes are implemented through a vertical shift of the ELA based on the temperature lapse rate (here, approximately $5.5 \mathrm{~K} \mathrm{~km}^{-1}$, giving an ELA sensitivity of approximately 180 $\left.\mathrm{m} \mathrm{K}^{-1}\right)^{33,36}$. Detailed surface-energy-balance models show close agreement with this value for glaciers in the Cordillera Blanca ${ }^{33,37}$.

Fig. $2 \mathrm{~b}$ shows the decadal-mean mass-balance profiles produced in response to the HadCRUT4-CW observations since 1880. Tropical glaciers are characterised by steep vertical gradients in ablation, rendering them particularly sensitive to climatic perturbation ${ }^{36}$. Starting from an 1880 baseline, the point at which anthropogenic warming begins to emerge (Fig. 2a), a warming of $0.25 \mathrm{~K}$ and $1.3 \mathrm{~K}$ (the respective anthropogenic contributions in 1941 and 2019) raises the ELA by 45 and $235 \mathrm{~m}$, respectively. At an elevation of $4600 \mathrm{~m}$, characteristic of the early $20^{\text {th }}$ Century ablation zone, these temperature changes increase the net ablation rate by $30 \%$ and $150 \%$, respectively. Given the linear 
relationship between temperature and ELA, the human-induced warming (as previously stated) and change in ELA are equal to 95\% of the observed temperature and modelled ELA changes, respectively.
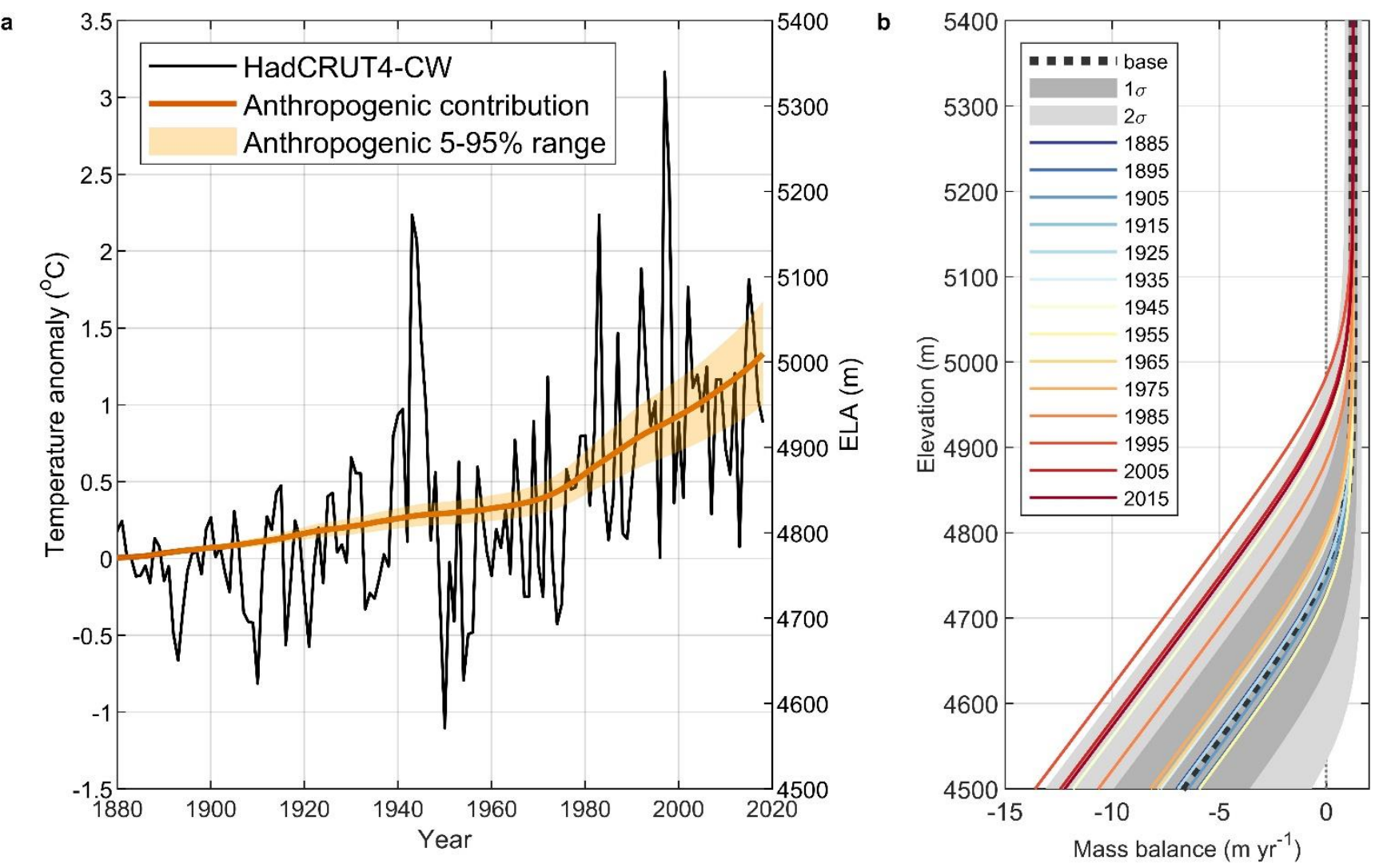

Figure 2: Regional observed and attributable temperature anomalies, and impacts on decadal-mean massbalance profile. (a) Annual-mean temperature (HadCRUT4-CW) expressed as anomalies from 1850-1880 and the resulting $E L A$, and the contribution of anthropogenic forcing to the observed temperature change, with its 5-95\% uncertainty ranges (shaded). (b) The resulting mass-balance profiles, plotted as decadal means, with the 1 and $2 \sigma$ mass-balance range around the base profile shown in grey. The glacier's 1880 profile (Fig. 3 ) is in mass balance for the base profile.

Next, we use a numerical flowline model of ice dynamics (see Methods) to evaluate the thickness profiles of the glacier during its retreat, the interaction of rising ELA and the valley geometry, and the natural glacier fluctuations in the absence of climate change. In the absence of direct observations, we estimate that the $19^{\text {th }}$ Century glacier terminus was situated $4.25 \mathrm{~km}$ along the flowline (see Methods). Uncertainty in the 1880 terminus position has no effect on present-day terminus position due to the geometry of the valley and the short response time of the modern glacier (Supplementary Materials, Fig. S1).

We model the response of Palcaraju glacier to regional annual temperature anomalies from three sources: HadCRUT4-CW (Fig. 2a), Berkeley Earth Land/Ocean observations ${ }^{38}$, and the European Centre for Medium-Range Weather Forecasts' $20^{\text {th }}$-Century reanalysis (ERA-20C) ${ }^{39}$. 


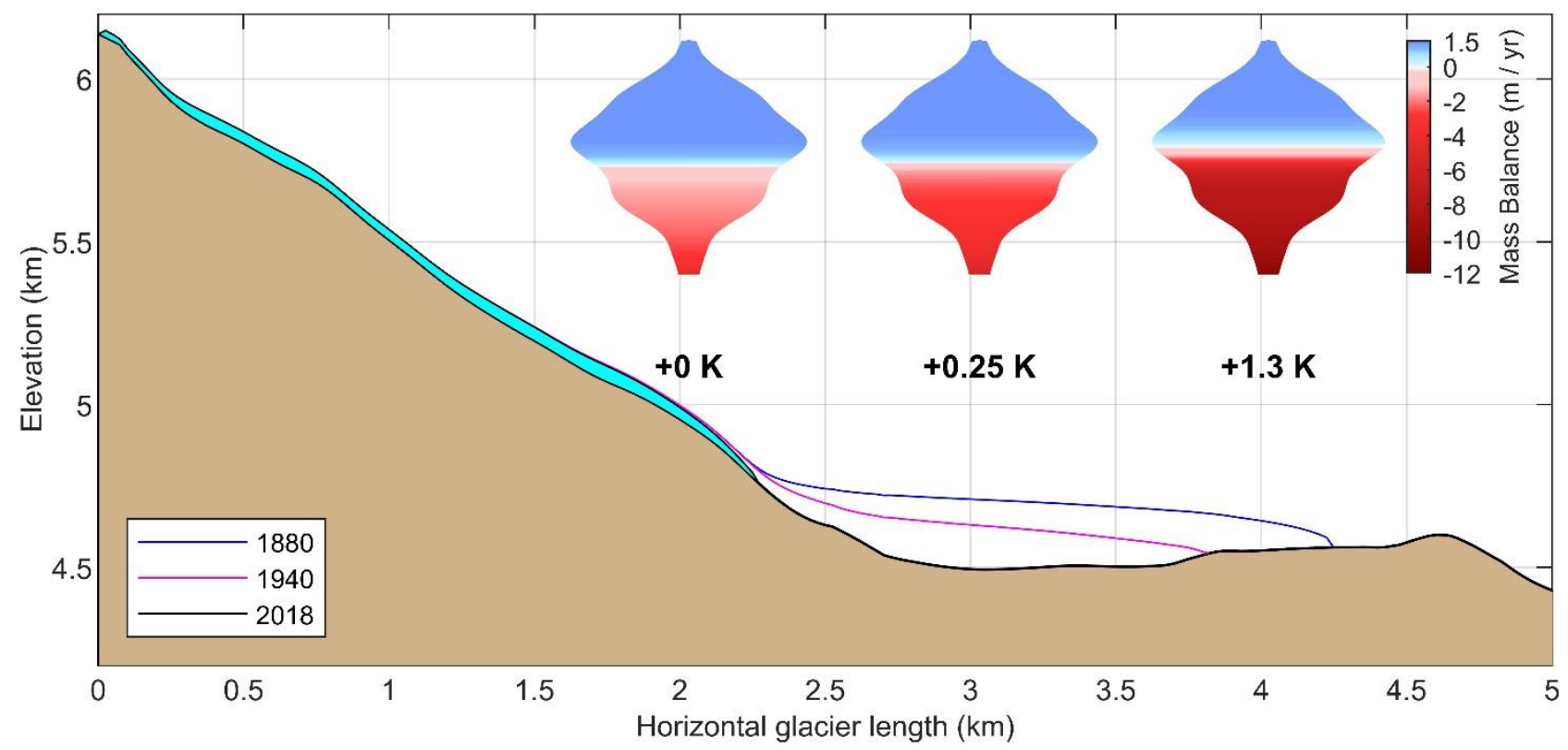

b

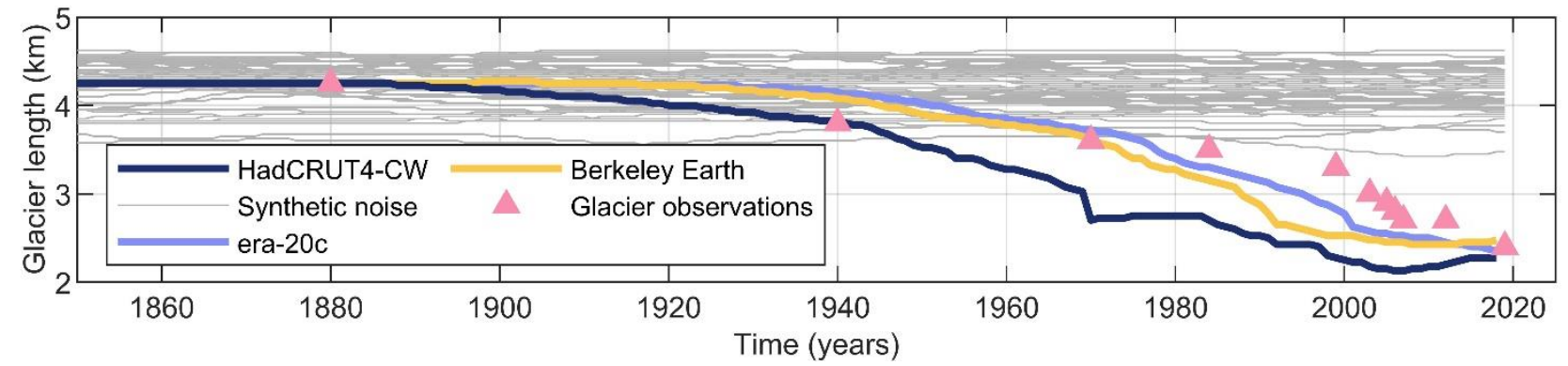

Figure 3: Mass-balance response to temperature change and modelled and observed retreat of Palcaraju glacier.

(a) Longitudinal profile of Palcaraju glacier in 1880 (blue), 1940 (magenta) and 2018 (cyan) in the HadCRUT4CW flowline model simulation; inset panels: idealised plan view of the glacier catchment with glacier width symmetrised about the flowline (approximately $5 \mathrm{~km}$ across at its widest point) and the mass-balance profile for the baseline, $+0.25 \mathrm{~K}$ and $+1.3 \mathrm{~K}$ climates, corresponding to the anthropogenic warming in 1880, 1940 and 2019 respectively. (b) The modelled glacier length for three temperature timeseries (for which temperature changes begin in 1880, 1890, and 1900 for HadCRUT4-CW, Berkeley Earth and ERA-20C, see Methods), compared with the estimated 1880 glacier terminus position and observed 1940-2019 positions (interpreted from aerial imagery, shown as magenta triangles) and synthetic natural glacier length variability (grey lines). Retreat since 1850 is estimated to be $1825 \mathrm{~m}$ in observations, compared with modelled values of $1950 \mathrm{~m}$ (HadCRUT4-CW), $1750 \mathrm{~m}$ (Berkeley Earth) and 1875 m (ERA-20C).

For all three temperature time series, the numerical model gives an overall retreat similar to that observed (Fig. 3a, b), with the timing of the period of most rapid retreat being less predictable. The planform inset panels in Fig. 3a show the regions of the glacier with net accumulation in blue and ablation in red, highlighting that this non-linear retreat is a geometric consequence of the steep vertical gradient in mass balance and shallow slopes in the lower valley. Applied to the 1880 profile, a warming of $0.25 \mathrm{~K}$ causes net ablation below the ELA to increase by $40 \%$, from $1.8 \mathrm{~m} \mathrm{yr}^{-1}$ to $2.5 \mathrm{~m} \mathrm{yr}^{-1}$, 
which cannot then be balanced by the $1.1 \mathrm{~m} \mathrm{yr}^{-1}$ of net accumulation above the ELA. For $1.3 \mathrm{~K}$ of warming, the average net ablation rate increases by $230 \%$ to $5.9 \mathrm{~m} \mathrm{yr}^{-1}$, and there is a $10 \%$ decrease in net accumulation above the ELA to $1.0 \mathrm{~m} \mathrm{yr}^{-1}$. Rising temperatures have expelled the glacier from the lower valley.

In the observations and our simulations, the glacier retreats rapidly between lengths of approximately 3.0 and $2.7 \mathrm{~km}$, taking 4 years in observations, and 1, 6, and 6 years in our modelled response to the HadCRUT4-CW, Berkeley Earth and ERA-20C timeseries, respectively. This period of rapid retreat is present in all simulations although its timing is sensitive to the warming history. It occurs in our model when thin ice above the slope break completely ablates, isolating a patch of stagnant ice on the lower slope. For the real glacier, the timing and nature of this retreat also depends on glacier-lake interactions and other processes not represented in our simulations. Our numerical model lacks lakeice dynamics (including glacier calving and thermal conduction) and debris cover (see Methods), which likely affects the match between the transient evolution of the observed and modelled termini (Fig. 3b).

Could the observed retreat have happened without anthropogenic global climate change? Interannual climate variability will cause glacier fluctuations even in the absence of large-scale climate change ${ }^{6,40}$. The standard deviations $(1 \sigma)$ of regional annual-mean temperature and precipitation are approximately $0.5 \mathrm{~K}$ and $0.2 \mathrm{~m} \mathrm{yr}^{-1}$, respectively, with some interannual persistence likely due to the influence of El Niño (see Methods). Applying this climatic variability to the 1880 glacier profile in the flowline model gives interannual variability in ELA and mass balance of $100 \mathrm{~m}$ and $0.75 \mathrm{~m} \mathrm{yr}^{-1}$ respectively (both $1 \sigma$ ) consistent with observations of similar glaciers ${ }^{41}$. We generate $10 \mathrm{kyr}$ of synthetic climate variability and find centennial-scale length fluctuations with a standard deviation $\left(\sigma_{L}\right)$ of $230 \mathrm{~m}$ (Fig. 3b, 4a). Fig. 4b and c show histograms of the 60-year and 140-year trends from the model output, compared with the observed retreat of Palcaraju between 1880 and 1940/2018, estimated at $550 \mathrm{~m}$ and $1850 \mathrm{~m}$, respectively. In both cases the rates of observed retreat are larger than any of the model output, indicating a large-scale climate change is a necessary condition for the glacier's observed length change to occur.

We then quantify the change in glacier length that can occur from natural variability alone $\left(\left.\Delta L\right|_{\text {null }}\right)$, including uncertainty in the glacier response time $(\tau)$ and the standard deviation of the glacier length $\left(\sigma_{L}\right)$. This analysis accounts for glaciers' amplification of the signal-to-noise ratio of climate change ${ }^{2}$ (Fig. 4d, Equation 4, see Methods) and generates probability density functions (PDFs) for 60-year and 140-year length trends in the absence of climate change (Fig. 4e, f, see Methods). Given our 
assumptions, we conclude that it is virtually certain ( $>99 \%$ probability) that the observed retreat of Palcaraju glacier could not have occurred due to natural variability alone and therefore that the observed large-scale climate warming that we attribute to human influence is a 'necessary cause' 42 of the observed retreat both to 1940 and to the present.
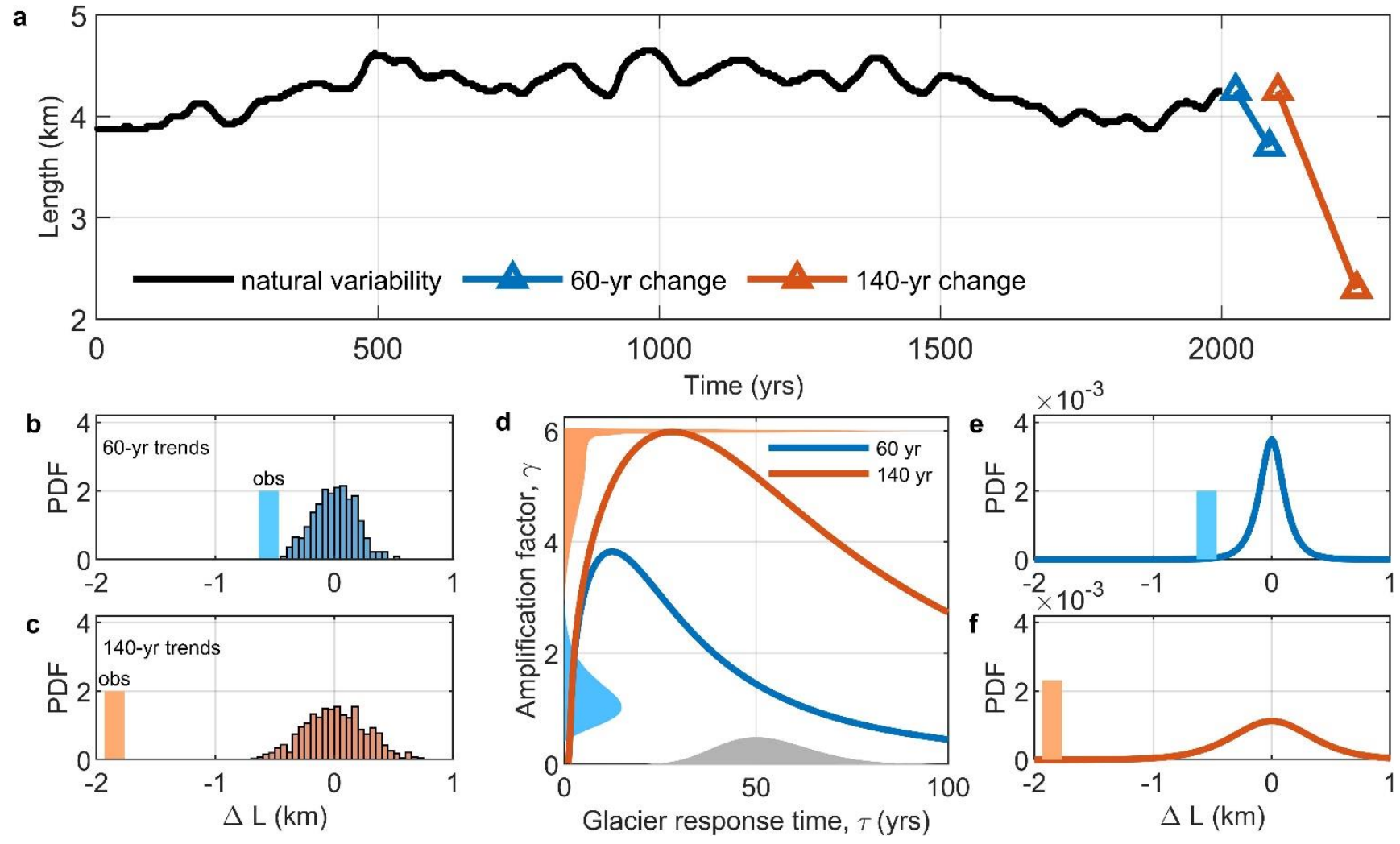

Figure 4: Analysis of the signal-to-noise ratio for Palcaraju glacier. (a) 2 kyr sample of glacier-length fluctuations occurring due to natural mass-balance variability alone (i.e. no temperature trend) taken from a $10 \mathrm{kyr}$ simulation (black) and compared with the observed retreat of Palcaraju glacier 1880-1940 (blue), and 18802019 (orange). (b) Histogram of modelled 60-year length changes in the $10 \mathrm{kyr}$ simulation of natural variability, as compared with the retreat observed between 1880-1940. (c) As (b), but for 140-year periods and compared with the observed length change between 1880 and 2019. (d) Transfer functions (solid lines) for calculating a glacier's amplification factor, (vertical axis, $\gamma$ ), for a 60-year (blue) and 140-year (orange) temperature trend, based on the glacier's $19^{\text {th }}$ Century response time (horizontal axis, $\left.\tau\right)^{2}$. We account for uncertainty in the value of $\tau$ in 1880 in the PDF on the horizontal axis (grey shading) and this gives rise to a PDF of values for $\gamma$ for each of the time periods (shaded PDFs on the vertical axis). (e) The PDF for $\left.\Delta L\right|_{\text {null }}$ in any 60-year period in a climate with interannual temperature variability but no climate change trend, compared with the observed retreat between 1880-1940 (vertical bar). (f) As (e) but for a 140-year period and as compared with 1880-2019.

The PDF of $\left.\Delta L\right|_{\text {null }}$ is symmetrical and centred over $0 \mathrm{~m}$. Thus, over a 140 -year period, the probability that the glacier would have extended is equal to the probability that it would have retreated, so our central (mean and median) estimate for $\left.\Delta L\right|_{\text {null }}$ is $0 \mathrm{~m}$. Consequently, our central estimate for the 
attributable fraction of the observed retreat to the observed temperature trend is $100 \%$. Above, we find that anthropogenic warming equals $95 \%$ of the observed temperature change in 1989-2018.

Further, for the 1940 retreat not to have been the result of early anthropogenic warming (and be explained only by natural variability) at the $90 \%$ confidence level, the pre-anthropogenic equilibrium terminus must have lain within $200 \mathrm{~m}$ of the observed 1940 position (Fig. 4e, Fig. S2d). This is inconsistent with the early $20^{\text {th }}$-Century retreat observed elsewhere in the Cordillera Blanca and the glacier-length sensitivity to climate change required for the formation of the $17^{\text {th }}$-Century moraine (see Methods, and refs ${ }^{14,43-45}$ ). It would also require some unknown factor to counter the impact of the $0.25 \mathrm{~K}$ of anthropogenic warming on the mass balance (Fig. 3a inset).

\section{Implications for GLOF hazard}

Our results establish that the present geometries of the glacier and lake are the result of anthropogenic climate change. What are the implications for GLOF hazard? GLOF hazard is the product of the probability of a GLOF event occurring and the event magnitude ${ }^{46}$. Previous work has shown that although a catastrophic breach of the moraine dam is unlikely, the present GLOF hazard from Lake Palcacocha is very high due to the significant likelihood of an avalanche or landslide inducing a moraine-overtopping wave ${ }^{12,19}$. We use two ranking methodologies to evaluate changes in GLOF hazard from Lake Palcacocha between the present day and the $19^{\text {th }}$ Century (see Methods and Tables S2 and S3). The ranking schemes indicate that the greatest influences on the increasing GLOF hazard are the steepness of the glacier snout, the growing lake area, and the glacier's retreat. The geometric method of ref. ${ }^{47}$ was developed for settings where a moraine-overtopping wave is the likely GLOF mechanism ${ }^{47}$. In line with previous application of this methodology to Palcacocha ${ }^{11}$ we confirm that the present GLOF hazard is categorised as 'very high' and find that it has increased from 'medium' in the $19^{\text {th }}$ Century. We compare these results with a geomorphological assessment methodology adapted from ref. ${ }^{48}$. It also presently ranks Lake Palcacocha in the highest GLOF hazard category, with the $19^{\text {th }}$ Century GLOF risk categorised as 'medium'. As a result of this increase in GLOF hazard, Lake Palcacocha is considered a serious threat to Huaraz, compelling the local authorities to implement hazard mitigation measures ${ }^{19}$.

The retreat of Palcaraju glacier, and resultant expansion of Lake Palcacocha, has increased both the probability and potential magnitude of a GLOF. In addition to the criteria assessed by the two hazard assessment methodologies employed here, permafrost degradation in response to rising temperatures can decrease slope stability, increasing the probability of rockfalls and landslides into glacial lakes. Further, the retreat of glaciers such as Palcaraju to steep mountain headwalls brings 
proglacial lakes closer to icy mountain flanks that have decreased stability due to glacier debuttressing ${ }^{48,49}$. The increase in lake size since the $19^{\text {th }}$ Century has also increased the likely GLOF volume, although neither methodology accounts for this change (the ref. ${ }^{48}$ methodology includes area but the lake is already in the highest area class in the $19^{\text {th }}$ Century).

The GLOF hazard posed by Lake Palcacocha to Huaraz has increased significantly due to the lake's expansion as Palcaraju glacier retreated and has now become a critical threat to Huaraz requiring engineered mitigation efforts. Given the assumptions in this three-step attribution, we find: (1) anthropogenic warming equals 95\% (85-105\%, 5-95\% confidence interval) of the observed warming in 1989-2018; (2) our central estimate is that the retreat of Palcaraju glacier is entirely the result of this warming; (3) the retreat cannot be explained by natural climatic variability alone; and (4) this retreat has substantially increased the GLOF hazard for Huaraz. Despite some uncertainty about the 1880 position of the glacier terminus, our analysis also provides strong evidence of anthropogenic influence on the 1941 GLOF, a mid-20 ${ }^{\text {th }}$ Century humanitarian catastrophe. For the attribution of the overall retreat of Palcaraju glacier, the $19^{\text {th }}$-Century position of the terminus is of lesser significance, and the present-day threat to Huaraz is a direct consequence of the anthropogenically-driven retreat of Palcaraju glacier.

Our analyses demonstrate the utility of risk-based approaches for evaluating the anthropogenic contribution to slow-onset, persistent hazards. The set of analyses presented in this paper could be applied to assess anthropogenic influence on GLOF hazard in any deglaciating alpine environment. Application of these methods in other locations would provide regional and global insight into human influence on present GLOF hazard and indicate how GLOF hazard may evolve under future climate change and where adaptation measures may need to be implemented.

\section{Corresponding author}

Correspondence should be addressed to Rupert Stuart-Smith: rupert.stuart-smith@ouce.ox.ac.uk

\section{Acknowledgements}

We are grateful to M. Baker and F. Otto for valuable comments and conversations, and to K. Haustein for providing Global Warming Index data. R.S.-S. acknowledges support from the School of Geography and the Environment, University of Oxford, the Oxford Sustainable Law Programme, and the Natural Environment Research Council grant NE/S007474/1, R.S.-S. \& G.H.R. from NSF PLR-1643299, and S.L. \& M.R.A from The Nature Conservancy-Oxford Martin School Climate Partnership. We gratefully acknowledge support from The Nature Conservancy-Oxford Martin School Climate Partnership and 
NSF CLD2019647 and the personal computing time given by the CPDN volunteers for the RCM data used for supporting our findings in this paper.

\section{Author contributions}

All authors planned the analyses which R.S.-S. and G.H.R. performed. All authors contributed to the interpretation of the results and to writing the manuscript.

\section{Competing interests}

The authors declare no competing financial or non-financial interests.

\section{References}

1. Zemp, M. et al. Historically unprecedented global glacier decline in the early 21st century. J. Glaciol. 61, 745-762 (2015).

2. Roe, G. H., Baker, M. B. \& Herla, F. Centennial glacier retreat as categorical evidence of regional climate change. Nat. Geosci. 10, 95-99 (2017).

3. Hock, R. et al. High Mountain Areas. in IPCC Special Report on the Ocean and Cryosphere in a Changing Climate (eds. Pörtner, H.-O. et al.) (IPCC, 2019).

4. Dussaillant, I. et al. Two decades of glacier mass loss along the Andes. Nat. Geosci. 12, 802-808 (2019).

5. Jóhannesson, T., Raymond, C. \& Waddington, E. Time-Scale for Adjustment of Glaciers to Changes in Mass Balance. J. Glaciol. 35, 355-369 (1989).

6. Roe, G. H. \& O'Neal, M. A. The response of glaciers to intrinsic climate variability: observations and models of late-Holocene variations in the Pacific Northwest. J. Glaciol. 55, 839-854 (2009).

7. Oerlemans, J. Holocene glacier fluctuations: is the current rate of retreat exceptional? Ann. Glaciol. 31, 39-44 (2000).

8. Sagredo, E. A. \& Lowell, T. V. Climatology of Andean glaciers: A framework to understand glacier response to climate change. Glob. Planet. Change 86-87, 101-109 (2012).

9. Harrison, S. et al. Climate change and the global pattern of moraine-dammed glacial lake outburst floods. Cryosphere 12, 1195-1209 (2018).

10. Schwanghart, W., Worni, R., Huggel, C., Stoffel, M. \& Korup, O. Uncertainty in the Himalayan energywater nexus: estimating regional exposure to glacial lake outburst floods. Environ. Res. Lett. 11, 074005 (2016).

11. Emmer, A. \& Vilímek, V. Review Article: Lake and breach hazard assessment for moraine-dammed lakes: an example from the Cordillera Blanca (Peru). Nat. Hazards Earth Syst. Sci. 13, 1551-1565 (2013).

12. Somos-Valenzuela, M. A., Chisolm, R. E., Rivas, D. S., Portocarrero, C. \& McKinney, D. C. Modeling a glacial lake outburst flood process chain: the case of Lake Palcacocha and Huaraz, Peru. Hydrol. Earth Syst. Sci. 20, 2519-2543 (2016).

13. Rivas, D. S., Somos-Valenzuela, M. A., Hodges, B. R. \& McKinney, D. C. Predicting outflow induced by moraine failure in glacial lakes: the Lake Palcacocha case from an uncertainty perspective. Nat. Hazards 
Earth Syst. Sci. 15, 1163-1179 (2015).

14. Lliboutry, L., Morales Arnao, B., Pautre, A. \& Schneider, B. Glaciological Problems Set by the Control of Dangerous Lakes in Cordillera Blanca, Peru. I. Historical Failures of Morainic Dams, their Causes and Prevention. J. Glaciol. 18, 239-254 (1977).

15. Emmer, A. Geomorphologically effective floods from moraine-dammed lakes in the Cordillera Blanca, Peru. Quat. Sci. Rev. 177, 220-234 (2017).

16. Portocarrero Rodríguez, C. A. The Glacial Lake Handbook: reducing risk from dangerous glacial lakes in the Cordillera Blanca, Peru. https://pdf.usaid.gov/pdf_docs/PBAAA087.pdf (USAID, Washington, D.C., 2014).

17. Drenkhan, F., Huggel, C., Guardamino, L. \& Haeberli, W. Managing risks and future options from new lakes in the deglaciating Andes of Peru: The example of the Vilcanota-Urubamba basin. Sci. Total Environ. 665, 465-483 (2019).

18. Vilímek, V., Zapata, M. L., Klimeš, J., Patzelt, Z. \& Santillán, N. Influence of glacial retreat on natural hazards of the Palcacocha Lake area, Peru. Landslides 2, 107-115 (2005).

19. Frey, H. et al. Multi-Source Glacial Lake Outburst Flood Hazard Assessment and Mapping for Huaraz, Cordillera Blanca, Peru. Front. Earth Sci. 6, 1-16 (2018).

20. Rabatel, A. et al. Current state of glaciers in the tropical Andes: a multi-century perspective on glacier evolution and climate change. Cryosph. 7, 81-102 (2013).

21. Wegner, S. A. Lo Que El Agua Se Llevó: Consecuencias y Lecciones del Aluvión de Huaraz de 1941. https://ia802205.us.archive.org/2/items/NotaTecnica7/Nota Tecnica 7 final.pdf (Perú Ministerio del Ambiente, Huaraz, 2014).

22. Huggel, C. et al. Anthropogenic climate change and glacier lake outburst flood risk: local and global drivers and responsibilities for the case of lake Palcacocha, Peru. Nat. Hazards Earth Syst. Sci. 20, 21752193 (2020).

23. Cochachin Rapre, A. \& Salazar Checa, C. Batimetría de la Laguna Palcacocha. http://repositorio.ana.gob.pe/bitstream/handle/20.500.12543/518/ANA0000304.pdf (Ministerio de Agricultura y Riego, Huaraz, 2016).

24. Kinzl, H. \& Schneider, E. Cordillera Blanca (Perú). (Universitäts-Verlag Wagner, Innsbruck, 1950).

25. Haustein, K. et al. A Limited Role for Unforced Internal Variability in Twentieth-Century Warming. J. Clim. 32, 4893-4917 (2019).

26. Haustein, K. et al. A real-time Global Warming Index. Sci. Rep. 7, 15417 (2017).

27. Allen, M. R. et al. Framing and Context. in Global Warming of $1.5^{\circ} \mathrm{C}$. An IPCC Special Report on the impacts of global warming of $1.5^{\circ} \mathrm{C}$ above pre-industrial levels and related global greenhouse gas emission pathways, in the context of strengthening the global response to the threat of climate change, (eds. Masson-Delmotte, V. et al.) 47-92 (IPCC/WMO, 2018).

28. Morice, C. P., Kennedy, J. J., Rayner, N. A. \& Jones, P. D. Quantifying uncertainties in global and regional temperature change using an ensemble of observational estimates: The HadCRUT4 data set. J. Geophys. Res. Atmos. 117, D08101 (2012). 
29. Cowtan, K. \& Way, R. G. Coverage bias in the HadCRUT4 temperature series and its impact on recent temperature trends. Q. J. R. Meteorol. Soc. 140, 1935-1944 (2014).

30. Gurgiser, W., Marzeion, B., Nicholson, L., Ortner, M. \& Kaser, G. Modeling energy and mass balance of Shallap Glacier, Peru. Cryosph. 7, 1787-1802 (2013).

31. Meier, M. F. \& Tangborn, W. V. Net Budget and Flow of South Cascade Glacier, Washington. J. Glaciol. 5, 547-566 (1965).

32. Kaser, G., Fountain, A. \& Jansson, P. A Manual for monitoring the mass balance of mountain glaciers with particular attention to low latitude characteristics; Technical documents in hydrology; Vol.:59; 2003. (UNESCO, Paris, 2003).

33. Sagredo, E. A., Rupper, S. \& Lowell, T. V. Sensitivities of the equilibrium line altitude to temperature and precipitation changes along the Andes. Quat. Res. 81, 355-366 (2014).

34. Malone, A. G. O., Doughty, A. M. \& Macayeal, D. R. Interannual climate variability helps define the mean state of glaciers. J. Glaciol. 65, 508-517 (2019).

35. Vuille, M. et al. Climate change and tropical Andean glaciers: Past, present and future. Earth-Science Rev. 89, 79-96 (2008).

36. Kaser, G. Glacier-climate interaction at low latitudes. J. Glaciol. 47, 195-204 (2001).

37. Stuart-Smith, R. F. Melt rate of Palcaraju glacier, Cordillera Blanca, Peru: attribution of anthropogenic influence and proposed methodology for calculating adaptation cost. (University of Oxford, Oxford, 2019).

38. Rohde, R. et al. A new estimate of the average earth surface land temperature spanning 1753 to 2011. Geoinfor. Geostat. http://dx.doi.org/10.4172/gigs.1000101 (2013).

39. Poli, P. et al. ERA-20C: An Atmospheric Reanalysis of the Twentieth Century. J. Clim. 29, 4083-4097 (2016).

40. Oerlemans, J. On the Response of Valley Glaciers to Climatic Change. in Glaciology and Quaternary Geology 353-371 (Springer Netherlands, Dordrecht, 1989).

41. Medwedeff, W. G. \& Roe, G. H. Trends and variability in the global dataset of glacier mass balance. Clim. Dyn. 48, 3085-3097 (2017).

42. Hannart, A., Pearl, J., Otto, F. E. L., Naveau, P. \& Ghil, M. Causal Counterfactual Theory for the Attribution of Weather and Climate-Related Events. Bull. Am. Meteorol. Soc. 97, 99-110 (2016).

43. Jomelli, V. et al. Fluctuations of glaciers in the tropical Andes over the last millennium and palaeoclimatic implications: A review. Palaeogeogr. Palaeoclimatol. Palaeoecol. 281, 269-282 (2009).

44. Georges, C. 20th-Century Glacier Fluctuations in the Tropical Cordillera Blanca, Perú. Arctic, Antarct. Alp. Res. 36, 100-107 (2004).

45. Kaser, G. \& Georges, C. Changes of the equilibrium-line altitude in the tropical Cordillera Blanca, Peru, 1930-50, and their spatial variations. Ann. Glaciol. 24, 344-349 (1997).

46. Raetzo, H., Lateltin, O., Bollinger, D. \& Tripet, J. P. Hazard assessment in Switzerland - Codes of Practice for mass movements. Bull. Eng. Geol. Environ. 61, 263-268 (2002).

47. Wang, W., Yao, T., Gao, Y., Yang, X. \& Kattel, D. B. A First-order Method to Identify Potentially Dangerous 
Glacial Lakes in a Region of the Southeastern Tibetan Plateau. Mt. Res. Dev. 31, 122 (2011).

48. Bolch, T. et al. Identification of potentially dangerous glacial lakes in the northern Tien Shan. Nat. Hazards 59, 1691-1714 (2011).

49. Haeberli, W. Mountain permafrost - research frontiers and a special long-term challenge. Cold Reg. Sci. Technol. 96, 71-76 (2013).

\section{Methods}

\section{Temperature data, lack of precipitation trend}

Given minimal seasonal temperature variations and consequent year-round ablation from tropical glaciers ${ }^{30,36}$, we model the evolution of Palcaraju glacier in response to annual-mean temperatures. We primarily use the UK MetOffice HadCRUT4-Cowtan/Way (HadCRUT4-CW) dataset ${ }^{28,29}$ as it provides continuous observations since 1850 and therefore a better pre-industrial baseline temperature for Peru than other observational datasets. Of the datasets considered, it also has an interannual temperature variability closest to the observed. The standard deviation of annual-mean temperature at the closest high-altitude meteorological station with an adequate record (the Mayor General FAP Armando Revoredo Iglesias Airport, 2,700m) is $0.62 \mathrm{~K}$ compared with $0.64 \mathrm{~K}$ for HadCRUT4-CW over the same period (1963-2018).

The baseline temperature was taken as the mean of 1850-1880. The observed warming between the baseline and most recent 10-year period (2009-2018) in HadCRUT4-CW is $1.01 \mathrm{~K}$. Station observations in the Tropical Andes give temperature trends of $+0.31 \mathrm{~K} /$ decade for $1969-1998$ and $+0.13 \mathrm{~K} /$ decade for $1983-2012^{50}$. Given these observed trends and the amplification of warming at higher altitudes ${ }^{51}$ (the mean elevation of the HadCRUT4-CW grid cell is $1333 \mathrm{~m}$ ) it is likely that our estimate of regional warming in the HadCRUT4-CW dataset is conservative. These factors do not affect the proportion of the trend attributable to anthropogenic influence. Further, surface-temperature simulations from the Hadley Centre regional climate model version 3P (HadRM3P) coupled to the global atmosphere model HadAM3P from the weather@home distributed climate modelling system ${ }^{52}$ give a temperature difference of around $1.5 \mathrm{~K}$ between the present and counterfactual (excluding human influence) climate (results not shown here).

A reduction in HadCRUT4-CW variability is evident prior to 1940 (Fig. 2a) and likely reflects greater reliance on interpolation over this period. The number of observations in the grid cell increases considerably from 1940, so this is the period regressed against the GWI. Regional anthropogenically-forced warming above the 1850-1880 baseline is calculated for $1989-2018$ as equalling $95 \%$ ( $85-105 \%$, 5-95\% range) of the observed temperature change. This value displays slight sensitivity to the choice of the present-day period. If using a 10-year period, following ref. ${ }^{27}$, regional anthropogenically-forced warming equals $120 \%$ (105-135\%, 5-95\% range) of the observed. The regression onto a global index assumes that the proportional contributions of anthropogenic and natural forcing to temperature change is the same at regional and global scales, justified by the absence of independent local factors that could create century-scale local climate trends. Such factors might include 14 
volcanic activity with effects localised to the Peruvian climate or significant local changes in albedo due to landcover alterations over the past 150 years. No such factors are known ${ }^{53}$.

We generate uncertainty estimates for the anthropogenic contribution to the temperature trends by regressing control simulations of 41 CMIP5 models (with no trends) against the GWI to calculate region-specific scaling factors for GWI. The product of GWI and these scaling factors creates a PDF of the degree that natural variability can project onto the observed temperature trend. The 5-to-95\% range of this PDF is the uncertainty in our estimate of the anthropogenic influence. We note that temperature variability may be higher at the local scale than simulated in CMIP5. However, in the Cordillera Blanca, the magnitude of interannual variability in gridscale and station data has been found to be similar over a 30 -year period ${ }^{54}$. Further, even given an extreme assumption that local interannual temperature variability is double that of the CMIP5 grid cell, the 5-to-95\% confidence range in the attribution statement broadens only slightly, from $85-105 \%$ to $70-120 \%$.

We take annual precipitation values as the accumulation zone mass balance (for 2006-2008) from the nearby Shallap glacier ${ }^{30}$. Previous studies have found that most individual meteorological stations do not show significant trends in precipitation over the $20^{\text {th }}$ Century ${ }^{35}$, although some have found an increasing trend in Cordillera Blanca precipitation in recent decades ${ }^{50}$. This glacier is also comparatively insensitive to variations in precipitation (discussed further below) and we do not apply a precipitation trend here.

\section{Interannual variability in temperature and precipitation, and persistence}

The HadCRUT4-CW temperature dataset gives a standard deviation of $0.55 \mathrm{~K}$ in annual-mean temperature for between 1880 and 2018, and the Legates and Wilmot precipitation dataset ${ }^{55}$ gives a standard deviation of 0.2 $\mathrm{m} \mathrm{yr}^{-1}$ in annual-mean precipitation (1900-2010, with no significant trend) ${ }^{55}$. We test for interannual persistence in the climate data using autoregression modelling ${ }^{56}$. The precipitation data is consistent with no persistence (i.e., white noise) but, for the HadCRUT4-CW temperature data, the best-fit autoregressive process is a firstorder (i.e., $A R(1))$ process with a lag-1 correlation coefficient of 0.32 , indicating a decorrelation time of around a year. This persistence is likely associated with the influence of El Niño. Our synthetic time series of stochastic climate variability includes this persistence, which enhances the magnitude of natural glacier variability ${ }^{2}$. We also applied the autoregression model to an ensemble of 41 models of CMIP5 control runs and found lesser levels of persistence than observed in almost all models. Since interannual persistence enhances the natural variability against which we compare the retreat of Palcaraju glacier, the modelled persistence in CMIP5 suggests our incorporation of interannual persistence is a conservative assumption.

\section{Vertical profile of mass balance}

The influence of precipitation on the vertical mass-balance profile is incorporated in our modelling by using the observed mass-balance profile from Shallap glacier (with similar aspect to Palcaraju). Ref. ${ }^{30}$ reports a vertical mass-balance gradient below the ELA $\left(b_{z}^{l}\right)$ of approximately 3 m.w.e. (metres of water equivalent) per $100 \mathrm{~m}$. The vertical mass-balance gradient above the ELA $\left(b_{z}^{u}\right)$ is approximately zero and the mass balance tapers 
smoothly to a constant of approximately 1.25 m.w.e. $\mathrm{yr}^{-1}$. We join these two domains smoothly with a tanh function of altitude, $z$ :

$$
\frac{d b}{d z}=b_{z}^{l}+\frac{\left(b_{z}^{u}-b_{z}^{l}\right)}{2}\left(1+\tanh \left(\frac{z-z_{e l a}}{\delta z}\right)\right)
$$

Where $z_{e l a}$ is the ELA and $\delta z$ is width of the transition zone (set as $\left.200 \mathrm{~m}\right) . b(z)$ is then obtained by integrating Equation 1 downwards from the top of the domain. Ref. ${ }^{30}$ reports an ELA for Shallap of $4985 \mathrm{~m}$ for 2006-7, and $4953 \mathrm{~m}$ for 2007-8, in close agreement with modern ELA we use for Palcaraju (Fig. 2a,b).

Tropical glaciers typically experience precipitation during the ablation season, and frequent changes in snow cover drive strong vertical gradients in albedo, and therefore mass balance ${ }^{57}$. The long ablation season of tropical glaciers also contributes to the strong vertical mass-balance gradient ${ }^{36,57}$, which is nearly constant from year to year. Over two years of observations from the nearby Shallap glacier, ref. ${ }^{30}$ report only a $3 \%$ difference in vertical gradient of ablation-zone mass balance, despite a $35 \%$ variation in accumulation. Consistent gradients can also be seen, for example, over 10 years at Uruashraju in Peru ${ }^{36}$, with similar results found for Zongo glacier in Bolivia ${ }^{58}$ and elsewhere in the tropics ${ }^{59}$. The near-constant year-on-year shape of the mass-balance profiles means that vertical and horizontal shifts of the mass-balance profile are a useful and efficient approximation to represent climate forcing ${ }^{31,32,34}$.

\section{Climate sensitivity of mass balance}

Following refs. ${ }^{34,36,60}$, the impact of temperature anomaly $\left(T^{\prime}\right)$ is implemented by vertically shifting the mass balance by an amount $z^{\prime}=T^{\prime} / \Gamma$, where $\Gamma=5.5 \times 10^{-3} \mathrm{~K} \mathrm{~km}^{-1}$ is the observed lapse rate ${ }^{30,57}$. We quantify the impact of a precipitation anomaly by adding a uniform anomaly to the mass-balance profile (a horizontal shift in Fig 2b). The steep mass-balance gradient in the ablation zone means that mass-balance variability is almost entirely due to temperature fluctuations. The interannual standard deviation of the ELA is $102 \mathrm{~m}$ with precipitation and temperature variability included, and $100 \mathrm{~m}$ when precipitation variability is omitted. For the 1880 glacier profile (Fig. 3a) this translates to an interannual standard deviation in mass balance of $0.78 \mathrm{~m} \mathrm{yr}^{-1}$ and $0.74 \mathrm{~m} \mathrm{yr}^{-1}$, respectively, when precipitation is, and is not, included.

Our calculations, provided in full in the Supplementary Materials, show that the ELA rises by $180 \mathrm{~m}$ for a $1 \mathrm{~K}$ temperature rise, in line with refs. ${ }^{33}(180 \mathrm{~m})$ and ${ }^{36}(182 \mathrm{~m})$. By contrast, a 10\% increase in annual-mean precipitation raises mass balance by approximately $0.1 \mathrm{~m} \mathrm{yr}^{-1}$, equivalent to a $13 \mathrm{~m}$ decrease in ELA. Normalising results from other tropical glaciers elsewhere in the published literature to this same mass-balance perturbation gives ELA decreases of $16 \mathrm{~m}$ (ref. ${ }^{33}$ ) or $8 \mathrm{~m}$ (ref. ${ }^{36}$ ). These ELA changes are much lower than those which result from a $1 \mathrm{~K}$ increase in temperature. Temperature trends are much more important than conceivable precipitation trends for the ELA and mass balance of Palcaraju glacier.

We further note that the mass-balance sensitivity to precipitation is reduced by Palcaraju glacier's wet climate which means that, unlike some tropical glaciers, sublimation contributes only a small portion of the mass 
budget. Drier glaciers with significant sublimation tend to have higher precipitation sensitivity ${ }^{61,62}$. Ref. ${ }^{30}$ reports that sublimation and evaporation accounts for about $10 \%$ of the ablation on Shallap glacier, consistent with the specific energy balance calculations of ref. ${ }^{62}$.

\section{Catchment geometry}

The geometry of the Palcaraju glacier catchment was obtained from Google Earth ${ }^{63}$. A central-catchment flowline was estimated to obtain a longitudinal profile of topography. We replaced the lake surface in Google Earth with the observed lake bathymetry ${ }^{13}$, and restored the topography of pre-1941 GLOF moraine at the end of the lake based on the reconstruction in ref. 13. The resulting profile is shown in Fig. 3a. The profile does not remove the existing ice in the upper catchment, but as its thickness is only a few tens of metres ${ }^{64}$, it has only a small effect on the profile. Ten approximately evenly spaced swaths along the profile were measured for catchment width and symmetrised about the central flowline to produce the idealised planform catchment geometry, shown in the inset panels in Fig. 3a.

\section{Numerical model}

The numerical model is the same as that used in ref. 6 , based on ref. ${ }^{65}$. The numerical model calculates ice flow from the shallow-ice approximation and Glen's Flow Law, and can be expressed as a pair of equations that are a function of time, $t$, and distance along the flowline, $x$ :

$$
\begin{gathered}
\frac{d h}{d t}=\frac{1}{w(x)} \frac{d}{d x}(w(x) F(x))+b(x) \\
F(x)=f_{d} \rho^{3} g^{3} h^{5}\left(\frac{d z_{s}}{d x}\right)^{3}
\end{gathered}
$$

where $h$ is ice thickness, $w$ is flowline width, $F$ is downslope flux, $b$ is mass balance, $f_{d}$ is the deformation constant, $\rho$ is ice density, $g$ is gravity, and $d z_{s} / d x$ is surface slope. Equations 2 and 3 constitute a nonlinear diffusion equation, wherein the ice flux is a sensitive function of the glacier shape. This numerical model is a useful tool for evaluating the glacier profiles that are consistent with the landscape geometry and the rising ELA associated with the observed climate trend. It also provides a method to estimate the time scale of the glacier response. This response time controls both the magnitude of the natural glacier fluctuations and the glacier's response to a climate trend ${ }^{5,66}$. The flowline model does not incorporate the effect of debris cover, subglacial till, or lake-terminus dynamics including ice calving and thermal conduction. Glacier flow may also have altered the subglacial topography which, after the retreat, became the lake bathymetry. As such, the flowline model is not intended or expected to produce an exact simulation of the glacier's evolution.

To estimate the glacier-length response to natural climate variability, we generate $10 \mathrm{kyr}$ of synthetic climate variability with the same statistical characteristics (variance and lag-1-year autocorrelation) as the observations. The resulting glacier-length fluctuations have a standard deviation of $235 \mathrm{~m}$. 


\section{Location of the $\mathbf{1 8 8 0}$ terminus}

In the absence of direct observations, we estimate the late $19^{\text {th }}$-Century terminus position, $L_{0}$. For our model, $L_{0}$ is the also the terminus position in equilibrium with the long-term average preindustrial climate. Centennialscale fluctuations about this equilibrium position result from the glacier's response to interannual climate variability (i.e., Fig $4 a)^{6,66,67}$. Our estimate for the magnitude of natural fluctuations is $\sigma_{L}=235 \mathrm{~m}$. $L_{0}$ was necessarily set back from the main terminal moraine as previous work has shown the moraine formed in the $17^{\text {th }}$ Century ${ }^{15}$, and it has not since been overtopped by natural glacier length fluctuations. Reconstructions from elsewhere in the Peruvian Andes also indicate that glaciers had pulled back from their $17^{\text {th }}$-Century maxima by the late $19^{\text {th }}$ Century ${ }^{43}$. It is also unlikely that $L_{0}$ was adjacent to the 1940 position: this would require larger natural variability for the glacier to have extended as far as the $17^{\text {th }}$-Century moraine, and these larger fluctuations would have taken the glacier further up the valley than the 1940 position, for which there is no evidence here or elsewhere in the region ${ }^{15,43}$. Glaciers with larger natural variability are also more sensitive to climate change ${ }^{66}$, implying an even more sensitive system than that modelled here. Finally, some glacial retreat in the Cordillera Blanca was observed as temperatures began to rise in the decades prior to $1940^{14,43-45}$. We therefore set $L_{0}=4250 \mathrm{~m}$. This places Palcaraju glacier's $19^{\text {th }}$-Century terminus approximately $2 \sigma_{L}$ from both the $17^{\text {th }}$-Century moraine and the 1940 position which is consistent with the glacier fluctuating within this portion of the valley in the $18^{\text {th }}$ and $19^{\text {th }}$ Centuries, but not outside of it (Fig. 3a, 4a). Placing $L_{0}$ halfway between the $17^{\text {th }}$-Century moraine and the 1940 moraine is conservative: it allows for the largest magnitude of natural variability and is consistent with the known bounds of the glacier and our direct modelling of $\sigma_{L}$. If the 1880 position of the terminus is placed significantly closer to the 1940 front (say $L_{0}<4 \mathrm{~km}$ ) it also becomes difficult to reconcile that 1880 location with the approximately $40 \%$ increase in net ablation rates that accompanies the $0.25 \mathrm{~K}$ of anthropogenic contribution to 1880 to 1940 warming, seen in the inset panels on Fig. 3.

\section{Signal-to-noise ratio}

A comprehensive uncertainty analysis of the change in glacier length that can occur from natural variability alone $\left(\left.\Delta L\right|_{\text {null }}\right)$ is possible. Ref. 2 used the property of glaciers' amplification of the signal-to-noise ratio of climate change, and that the amplification is greatest at intermediate glacier response times, to show that,

$$
\left.\Delta L\right|_{n u l l}=\left.\sigma_{L} \cdot \gamma\left(t_{0}, \tau\right) \cdot s_{b}\right|_{n u l l}
$$

where $\gamma\left(t_{0}, \tau\right)$ is an amplification factor that depends only on the duration of the change $\left(t_{0}\right)$ and the glacier response time $(\tau)$, and $\left.s_{b}\right|_{\text {null }}$ is the signal-to-noise ratio of the mass balance $(b)$ due to the observed interannual variability (i.e. $\left.\Delta b / \sigma_{b}\right)$. The glacier response time equals the characteristic ice thickness $(H)$ in the ablation zone divided by the (negative) net mass balance at the terminus $\left(b_{t}\right)$ and affects both the amplitude and rate of change of length possible over a given time period, $t_{0}$. For the glacier's 1880 geometry, we estimate

the response time as: $\tau=\frac{H}{-b_{t}} \approx 150 \mathrm{~m} / 3 \mathrm{~m} \mathrm{yr}^{-1} \approx 50 \mathrm{yr}$. We have model estimates of $\tau$ and $\sigma_{L}$, but they are uncertain. We represent uncertainty in $\tau$ with a gamma function with $95 \%$ confidence bounds of 25 to 75 years 
(Fig. 4d). Similarly, for $\sigma_{L}$ we give $95 \%$ confidence bounds of 115 to $345 \mathrm{~m}$ (Fig. S2C). $\left.s_{b}\right|_{\text {null }}$ is taken from the observed interannual variability and follows the Student's t-distribution ${ }^{2}$. Through Equation 4, these PDFs yield PDFs for 60-yr and 140-yr length trends in the absence of a climate change (Fig 4e,f).

Equation 4 is derived in ref. 2 based on a three-stage model of glacier dynamics, whose parameters are governed by the glacier's geometry and climatic setting ${ }^{66}$. The model has been shown to accurately emulate glacier fluctuations in numerical models of ice-flow dynamics ${ }^{66-68}$. The three-stage model is linear, and although we do not expect linearity to apply over the whole valley profile, our goal is to characterise the much smaller fluctuations due to natural variability. The synthetic mass balance time series we apply to the numerical model (Fig 4a) is normally distributed, so the resulting glacier fluctuations are also approximately normally distributed, supporting the linearity approximation.

\section{GLOF hazard assessment}

We use two methods for identifying dangerous glacial lakes. The method proposed by ref. ${ }^{47}$ was developed for assessing settings where the likely GLOF mechanism would be a moraine-overtopping wave induced by an ice avalanche, as is the case with Lake Palcacocha. GLOF hazard is quantified using the glacier area, the distance between the lake and glacier terminus, the slope between the lake and glacier, the mean slope of the moraine dam, and the glacier-snout steepness. Since Lake Palcacocha is in direct contact with Palcaraju glacier, we follow ref. ${ }^{47}$ and use the gradient of the glacier snout, defined as the glacier area within $500 \mathrm{~m}$ horizontal distance from the terminus, in place of the slope between the lake and glacier. The area of the glacier is taken from the Global Land Ice Measurements from Space (GLIMS) database ${ }^{69}$ (value is for 2015). The mean slope of the moraine dam before and after the 1941 GLOF (for the pre-industrial and present-day calculations, respectively) was taken from ref. 12, and the slope of the glacier snout from our model reconstructions of the 1880 and present-day glacier geometries. Our assessment gives the same numerical value for present GLOF hazard as ref. 11 , using this methodology.

We supplement these calculations with an independent assessment adapted from ref. ${ }^{48}$. This methodology uses 11 weighted stability parameters, which relate to characteristics of the lake, lake surroundings and adjacent glaciers, and potential impact on downstream areas. Parameters are ranked according to influence on GLOF occurrence. We exclude two parameters from our analysis (glacier terminus slope and glacier velocity) since our analysis concerns present-day GLOF hazard and these factors are used to identify glacial lakes where future rapid expansion may occur, increasing the hazard. We recalculated the weight factors for the remaining nine parameters according to the method provided in ref. ${ }^{48}$ (values provided in Table S3), which also instructs that flash-flood risk is set to zero if a debris flow is expected. We estimated the $19^{\text {th }}$-Century lake area as approximately $150,000 \mathrm{~m}^{2}$ based on our modelling estimates of glacial retreat prior to 1941 , and the estimated area of $303,000 \mathrm{~m}^{2}$ immediately prior to the $1941 \mathrm{GLOF}^{70}$. The lake area was $518,000 \mathrm{~m}^{2}$ in $2016^{23}$. This method assesses hazard as 'high' if the four most important factors, or a combination of factors which, combined, are equal to the sum of the weights of the four most important factors, apply. 
Data availability: All climate data (observations and reanalysis) that support the findings of this study are publicly available from the KNMI Climate Explorer (https://climexp.knmi.nl/) except the Mayor General FAP Armando Revoredo Iglesias Airport station data which was downloaded from the Center for Climate and Resilience Research (University of Chile) Climate Explorer (http://explorador.cr2.cl/). All CMIP5 model data used in this study are available in public repositories, e.g. https://esgf-node.IInl.gov/search/cmip5/. The model data used here was stored on the Natural Environment Research Council's (NERC) designated data centre for the atmospheric sciences, BADC (British Atmospheric Data Centre). The Global Warming Index data are available from the corresponding author upon request.

Code availability: code will be available on request to the corresponding author.

\section{References}

50. Schauwecker, S. et al. Climate trends and glacier retreat in the Cordillera Blanca, Peru, revisited. Glob. Planet. Change 119, 85-97 (2014).

51. Mackintosh, A. N., Anderson, B. M. \& Pierrehumbert, R. T. Reconstructing Climate from Glaciers. Annu. Rev. Earth Planet. Sci. 45, 649-80 (2017).

52. Guillod, B. P. et al. weather@home 2: validation of an improved global-regional climate modelling system. Geosci. Model Dev. 10, 1849-1872 (2017).

53. Betts, R. Biogeophysical impacts of land use on present-day climate: near-surface temperature change and radiative forcing. Atmos. Sci. Lett. 2, 39-51 (2001).

54. Hofer, M., Mölg, T., Marzeion, B. \& Kaser, G. Empirical-statistical downscaling of reanalysis data to highresolution air temperature and specific humidity above a glacier surface (Cordillera Blanca, Peru). J. Geophys. Res. 115, D12120 (2010).

55. Legates, D. R. \& Willmott, C. J. Mean seasonal and spatial variability in gauge-corrected, global precipitation. Int. J. Climatol. 10, 111-127 (1990).

56. Box, G. E. P., Jenkins, G. M., Reinsel, G. C. \& Ljung, G. M. Time Series Analysis: Forecasting and Control. (Wiley, Hoboken, 2008).

57. Sicart, J.-E., Hock, R., Ribstein, P., Litt, M. \& Ramirez, E. Analysis of seasonal variations in mass balance and meltwater discharge of the tropical Zongo Glacier by application of a distributed energy balance model. J. Geophys. Res. 116, D13105 (2011).

58. Sicart, J. E., Ribstein, P., Francou, B., Pouyaud, B. \& Condom, T. Glacier mass balance of tropical Zongo glacier, Bolivia, comparing hydrological and glaciological methods. Glob. Planet. Change 59, 27-36 (2007).

59. Kaser, G. \& Osmaston, H. A. Tropical Glaciers. (Cambridge University Press, Cambridge, 2002).

60. Kaser, G., Juen, I., Georges, C., Gómez, J. \& Tamayo, W. The impact of glaciers on the runoff and the reconstruction of mass balance history from hydrological data in the tropical Cordillera Bianca, Perú. J. Hydrol. 282, 130-144 (2003).

61. Mölg, T. \& Hardy, D. R. Ablation and associated energy balance of a horizontal glacier surface on Kilimanjaro. J. Geophys. Res. D Atmos. 109, D16104 (2004). 
62. Rupper, S. \& Roe, G. H. Glacier changes and regional climate: A mass and energy balance approach. J. Clim. 21, 5384-5401 (2008).

63. Google Earth. Lake Palcacocha $9^{\circ} 23^{\prime} 42^{\prime \prime} \mathrm{S} 77^{\circ} 22^{\prime} 42^{\prime \prime}$ W, elevation 8.8km. (2018).

64. Farinotti, D. et al. A consensus estimate for the ice thickness distribution of all glaciers on Earth. Nat. Geosci. 12, 168-173 (2019).

65. Oerlemans, J. An attempt to simulate historic front variations of Nigardsbreen, Norway. Theor. Appl. Climatol. 37, 126-135 (1986).

66. Roe, G. H. \& Baker, M. B. Glacier response to climate perturbations: an accurate linear geometric model. J. Glaciol. 60, 670-684 (2014).

67. Roe, G. H. \& Baker, M. B. The response of glaciers to climatic persistence. J. Glaciol. 62, 440-450 (2016).

68. Christian, J. E., Koutnik, M. \& Roe, G. H. Committed retreat: controls on glacier disequilibrium in a warming climate. J. Glaciol. 64, 675-688 (2018).

69. Cogley, J. G. (submitter), Kienholz, C., Miles, E. S., Sharp, M. J. \& Wyatt, F. GLIMS Glacier Database. (2015) http://dx.doi.org/10.7265/N5V98602.

70. Mergili, M. et al. Reconstruction of the 1941 GLOF process chain at Lake Palcacocha (Cordillera Blanca, Peru). Hydrol. Earth Syst. Sci. 24, 93-114 (2020). 